\title{
Table of national laws
}

Age Discrimination in Employment Act 1967 (US)

Fair Labor Standards Act 1994 (US)

Irish Trades Union Act 1941 (Ireland)

Irish Trades Union Act 1975 (Ireland)

Industrial Relations Act 1990 (Ireland)

Joint Regulation of Working Life Act 1976 (Sweden)

New Works Constitution Act 2001 (Germany)

Trade Union Law 1982 (France)

Trade Union Recognition Act 2000 (Ireland) 